\title{
Platelets: The Emerging Clinical Diagnostics and Therapy Selection of Cancer Liquid Biopsies
}

\author{
Yiming Meng' \\ Jing Sun ${ }^{2}$ \\ Yang Zheng ${ }^{3}$ \\ Guirong Zhang' \\ Tao Yu (D) ${ }^{4}$ \\ Haozhe Piao ${ }^{1,5}$ \\ 'Department of Central Laboratory, \\ Cancer Hospital of China Medical \\ University, Liaoning province Cancer \\ Hospital, Shenyang, I I0042, People's \\ Republic of China; ${ }^{2}$ Department of \\ Biobank, Cancer Hospital of China \\ Medical University, Liaoning Province \\ Cancer Hospital, Shenyang, I I0042, \\ People's Republic of China; ${ }^{3}$ Department \\ of Clinical Laboratory, Cancer Hospital of \\ China Medical University, Liaoning \\ Province Cancer Hospital, Shenyang, \\ I I0042, People's Republic of China; \\ ${ }^{4}$ Department of Medical Imaging, Cancer \\ Hospital of China Medical University, \\ Liaoning Province Cancer Hospital, \\ Shenyang, I 10042, People's Republic of \\ China; ${ }^{5}$ Department of Neurosurgery, \\ Cancer Hospital of China Medical \\ University, Liaoning Province Cancer \\ Hospital, Shenyang, I I0042, People's \\ Republic of China
}

Correspondence: Tao Yu Department of Medical Imaging, Cancer Hospital of China Medical University, Liaoning Province Cancer Hospital, No. 44, Xiaoheyan Road, Dadong District, Shenyang, I 10042, People's Republic of China

Tel +86- |804I394586

Fax +86-24-31916472

Email taoyulnszlyy@sina.com

Haozhe Piao

Department of Central Laboratory Cancer Hospital of China Medical

University, Liaoning Province Cancer

Hospital, No. 44, Xiaoheyan Road,

Dadong District, Shenyang, I I 0042,

People's Republic of China

Tel +86-|3|66765053

Fax+86-24-31916472

Email haozhepiaolnzlyy@sina.com

\begin{abstract}
Due to the inherent molecular heterogeneity of metastatic tumours and the dynamic evolution ability of tumour genomes, tumour tissues obtained through biopsy and other methods cannot capture all of the features of tumour genomes. A new diagnostic concept called "liquid biopsy" has received widespread attention in recent years. Liquid biopsy has changed the clinical practice of oncology and is widely used to guide targeted drug utilization, monitor disease progression and track drug resistance. The latest research subject in liquid biopsy is platelets. Platelets originate from multifunctional haematopoietic stem cells in the bone marrow haematopoietic system. They are small cells from the cytoplasm of bone marrow megakaryocytes. Their main physiological functions are to participate in the processes of physiological haemostasis and coagulation. Tumour cells transfer biomolecules (such as RNA) to platelets through direct contact and release of exosomes, which changes the platelet precursor RNA. Under the stimulation of tumour cells and the tumour microenvironment, platelet precursor mRNA is spliced into mature RNA and converted into functional protein to respond to external stimuli, forming tumoureducated platelets (TEPs). The detection of TEPs in the peripheral blood of patients is expected to be used in clinical tumour diagnosis. This emerging liquid biopsy method can replace and supplement the current tumour detection methods. Further research on the role of platelets in tumour diagnosis will help provide a novel theoretical basis for clinical tumour diagnosis.
\end{abstract}

Keywords: liquid biopsy, platelet, diagnosis, RNA, noninvasive

\section{Introduction}

Over the years, through the unremitting efforts of the majority of medical personnel, great progress has been made in the treatment of various tumours (including surgical resection, concurrent radiotherapy, chemotherapy, and immunotherapy), but most are limited to treating early tumours. ${ }^{1}$ The treatment of moderate and advanced cancers is still facing great difficulties, so the early diagnosis of tumours is particularly important. The early clinical symptoms of most tumours are not typical, and routine physical examinations, including imaging, endoscopy and disease examinations, cannot accurately detect malignancies. ${ }^{2}$ Therefore, there is an urgent need for a more accurate, efficient and convenient examination method to diagnose early tumours and closely monitor dynamic changes in the tumours after treatment.

With the continuously elucidated mechanisms of tumour occurrence, drug resistance, and tumour microenvironment regulation, liquid biopsy will be increasingly widely utilized in the clinical field. Liquid biopsy provides an important basis 
for early diagnosis and screening, efficacy monitoring, prognostic evaluation and drug guidance. Liquid biopsy, including circulating tumour cells, circulating tumour DNA, microribonucleic acid, extracellular vesicles, exosomes, and TEPs in the peripheral blood of tumour patients, has reached the demand of tumour screening and early diagnosis by a non-invasive method. ${ }^{3,4}$ Platelets, known for their haemostatic effects, also play a significant role in the growth and development of tumours. ${ }^{5}$ Under the stimulation of various stimulating factors, platelets in an ordinary resting state release their intracellular granular material, and then the granule protein is integrated into the endothelium of its plasma membrane, which is called platelet activation. Platelet activation is the initiation process that mediates inflammation and tumourrelated functions. ${ }^{6-8}$ When platelet surface receptors are activated, specific precursor mRNA splicing will occur, resulting in a unique mRNA expression profile that can be used for tumour diagnosis and prognosis. This review will illustrate and reveal the latest progress of platelets in tumour liquid biopsy in recent years.

\section{The Vital Role of Platelet Count in Tumour Detection}

Platelets have two major physiological properties: adhesion and aggregation. ${ }^{9}$ More precisely, fibrinogen is the major ligand for platelet $\alpha$ IIB $\beta 3$ integrin during platelet aggregation. ${ }^{10}$ The aggregation of platelets can promote the release of numerous factors that play an important role in the study of coagulation. Platelets are not only involved in haemostasis but also act as regulatory factors within the immune system. ${ }^{11,12}$ In patients with malignant tumours, there will be changes in systemic platelet activation. The most prominent characteristic is platelet count elevation, which induces a high coagulation status and finally results in the formation of thrombi and fibrinogen increases. ${ }^{13}$ In addition, multiple reports have demonstrated that in patients with prostate cancer accompanied by diffuse intravascular coagulation disorders, their platelet and fibrinogen levels are increased sharply. ${ }^{14,15}$ The increase in platelets is beneficial for the activation of tumour cells; therefore, the platelet count may be one of the markers of tumour progression. Beili Wang and colleagues found that the platelet count may be a potential biomarker for predicting the prognosis of patients with hepatitis B virusrelated hepatocellular carcinoma treated with catheter arterial chemoembolization. ${ }^{16}$ The study of Oh SE et al also found that platelet count may be a cost-effective biomarker for screening and monitoring poor prognosis of gastric cancer patients who have undergone radical surgery. ${ }^{17}$ Zheng RR and colleagues found that the combination of platelet count and International Federation of Obstetrics and Gynaecology (FIGO) staging improved the predictive performance of FIGO staging and provided additional risk stratification for patients with operable cervical cancer. ${ }^{18}$ Väyrynen JP and colleagues found that high platelet counts are associated with systemic inflammation in colorectal cancer (CRC). ${ }^{19}$ However, this study was unable to prove a statistically significant correlation between platelet count, aspirin use and tumour infiltrating immune cell density. The study by Midorikawa $\mathrm{Y}$ and colleagues also found that thrombocytopaenia predicts a poor prognosis for patients with liver cirrhosis and liver cancer, while thrombocytopaenia predicts a poor prognosis for patients without cirrhosis. ${ }^{19}$ In brief, the relevant studies are listed in Table $1 .^{16-39}$

\section{Research Progress on the Mean Platelet Volume (MPV) in Malignant Tumours}

Platelets play an important role in the coagulation process. Simultaneously, changes within various indicators in platelets directly or indirectly reflect the characteristics of inflammation. One of the often-overlooked indicators is mean platelet volume (MPV). ${ }^{40}$ It is generally believed that MPV directly reflects the average volume of platelets and indirectly reflects the rate of platelet production. There is a clear range of MPV in normal humans, and its detection and evaluation are mostly used for diseases such as blood diseases. $^{41,42}$ In the latest research, scientists found that abnormalities in MPV may indicate the occurrence of certain diseases before the platelet count and clinical symptoms become abnormal. ${ }^{43}$ More precisely, MPV has a significant correlation with the occurrence and development of inflammation, and the increase in tissue penetration caused by inflammation is a key factor in the escalation of platelet volume. ${ }^{44}$ For example, studies have shown that in gastric cancer, liver cancer, lung cancer, and endometrial cancer, increased MPV can be used as a tumour biomarker. The related data are listed in Table 2.22,23,27,28,45-75. Differentiating benign and malignant thyroid nodules is a breakthrough point in clinical diagnosis. The study of Sit $M$ found that an increase in MPV can be regarded as an auxiliary diagnostic tool to distinguish malignant and benign 
Table I Summary of the Correlation of Platelet Count with Tumor

\begin{tabular}{|c|c|c|}
\hline $\begin{array}{l}\text { Disease Model/Patient } \\
\text { Type }\end{array}$ & Comments & Ref. \\
\hline $\begin{array}{l}\text { Hepatocellular carcinoma } \\
\text { (HCC) }\end{array}$ & $\begin{array}{l}\text { Platelet count may be a potential biomarker for predicting the prognosis of patients with } \\
\text { hepatitis B virus-related hepatocellular carcinoma treated with catheter arterial } \\
\text { chemoembolization. }\end{array}$ & Wang $B$ et al, ${ }^{15}$ \\
\hline $\mathrm{HCC}$ & $\begin{array}{l}\text { Platelet count was better than indocyanine green (ICG) RI5 level in predicting the } \\
\text { occurrence of liver failure (PHLF) in patients with HCC with preserved liver function. }\end{array}$ & $\begin{array}{l}\text { Tomimaru } \\
\text { Y et al, }{ }^{20}\end{array}$ \\
\hline $\mathrm{HCC}$ & $\begin{array}{l}\text { Decreased platelet cell count and higher MPV are associated with better prognosis in } \\
\text { patients with advanced HCC. }\end{array}$ & $\begin{array}{l}\text { Scheiner } \\
\text { B et al, }\end{array}$ \\
\hline Liver cancer & $\begin{array}{l}\text { Decrease in the number of platelets indicates a poor prognosis for patients with liver } \\
\text { cirrhosis and liver cancer, while an increase in platelet count indicates a poor prognosis for } \\
\text { patients without cirrhosis. }\end{array}$ & $\begin{array}{l}\text { Midorikawa } \\
\text { Y et al, }{ }^{19}\end{array}$ \\
\hline Gastric cancer & $\begin{array}{l}\text { Platelet count may be a cost-effective biomarker for screening and monitoring poor } \\
\text { prognosis of gastric cancer patients who have undergone radical surgery. }\end{array}$ & Oh SE et al, ${ }^{16}$ \\
\hline Lung cancer & $\begin{array}{l}\text { Increased platelet count and decreased MPV were the poor prognosis of lung cancer } \\
\text { patients, and platelet count was also associated with bone, soft tissue, lymph node } \\
\text { metastasis and malignant pleural effusion. }\end{array}$ & Ohuchi $M$ et al, ${ }^{22}$ \\
\hline Lung adenocarcinoma (ADC) & $\begin{array}{l}\text { Even if the platelet count is within the reference range, elevated platelet counts were } \\
\text { significantly associated with high lymph node metastasis rates in patients with ADC. }\end{array}$ & $\mathrm{Qu} \mathrm{CH}$ et al, ${ }^{23}$ \\
\hline $\begin{array}{l}\text { Non-small cell lung cancer } \\
\text { (NSCLC) }\end{array}$ & $\begin{array}{l}\text { Platelet count could predict the prognosis of patients with NSCLC treated with epidermal } \\
\text { growth factor receptor tyrosine kinase inhibitors (EGFR-TKIs). }\end{array}$ & $X u L$ et al, ${ }^{24}$ \\
\hline Cervical cancer & $\begin{array}{l}\text { The combination of platelet count and International Federation of Obstetrics and } \\
\text { Gynecology (FIGO) staging improves the predictive performance of FIGO staging and } \\
\text { provides additional risk stratification for patients with operable cervical cancer. }\end{array}$ & Zheng RR et al, ${ }^{17}$ \\
\hline $\begin{array}{l}\text { Head and neck squamous cell } \\
\text { carcinoma (HNSCC) }\end{array}$ & $\begin{array}{l}\text { Univariate analysis showed that platelet count was significantly correlated with the survival } \\
\text { rate of patients with HNSCC. However, in multivariate analysis, platelet count lost its } \\
\text { prognostic ability. }\end{array}$ & Pardo $L$ et al, ${ }^{25}$ \\
\hline Colorectal cancer (CRC) & MPV/platelet count may be helpful in the diagnosis of CRC. & Wu YY et al, ${ }^{26}$ \\
\hline CRC & $\begin{array}{l}\text { Neutrophil to lymphocyte ratio (NLR), platelet to lymphocyte ratio (PLR) and mean platelet } \\
\text { volume (MPV) may be useful markers for the diagnosis and early recognition of different } \\
\text { stages of CRC. }\end{array}$ & $\begin{array}{l}\text { Stojkovic } \\
\text { Lalosevic } \\
\text { M et al, }\end{array}$ \\
\hline CRC & $\begin{array}{l}\text { High platelet counts were associated with systemic inflammation of CRC. However, this } \\
\text { study was unable to prove a statistically significant correlation between platelet count, } \\
\text { aspirin use and tumor infiltrating immune cell density. }\end{array}$ & $\begin{array}{l}\text { Väyrynen JP } \\
\text { et al, }{ }^{18}\end{array}$ \\
\hline Rectal cancer & $\begin{array}{l}\text { The mortality of rectal cancer patients with high platelet counts before surgery is higher than } \\
\text { that of rectal cancer patients with low platelet levels. Research results suggest that preoperative } \\
\text { platelet count can be used as an important indicator for predicting the prognosis of rectal } \\
\text { cancer, but its prognostic value for colon cancer needs to be further clarified. }\end{array}$ & Chen LL et al, ${ }^{28}$ \\
\hline Rectal cancer & $\begin{array}{l}\text { In locally advanced rectal cancer, elevated platelet count before neoadjuvant radiotherapy } \\
\text { and chemotherapy is a sign of poor prognosis. }\end{array}$ & Belluco $\mathrm{C}$ et $\mathrm{al}^{29}$ \\
\hline Ovarian cancer & $\begin{array}{c}\text { In multivariate analysis, age, CAI } 25 \text { and thrombocytosis independently predicted the } \\
\text { presence of ovarian malignancies. }\end{array}$ & $\begin{array}{l}\text { Watrowski } \\
\mathrm{R} \text { et } \mathrm{al},{ }^{30}\end{array}$ \\
\hline
\end{tabular}

(Continued) 
Table I (Continued).

\begin{tabular}{|c|c|c|}
\hline $\begin{array}{l}\text { Disease Model/Patient } \\
\text { Type }\end{array}$ & Comments & Ref. \\
\hline Ovarian cancer & $\begin{array}{l}\text { Mean platelet volume (MPV), neutrophil to lymphocyte ratio (NLR) and platelet count in the } \\
\text { detection of malignant ovarian tumors have been evaluated as useful new markers. }\end{array}$ & Yilmaz $\mathrm{E}$ et $\mathrm{al},{ }^{31}$ \\
\hline Epithelial ovarian cancer (EOC) & $\begin{array}{l}\text { Platelet count can be used as a biomarker to monitor EOC recurrence and predict } \\
\text { treatment response. }\end{array}$ & Hu $Q$ et $a l,{ }^{32}$ \\
\hline Prostate cancer & $\begin{array}{l}\text { The results of the study indicate that performance status (PS) and platelet count are } \\
\text { independent prognostic factors for evaluating disease-specific survival (DSS) in patients with } \\
\text { metastatic prostate cancer receiving endocrine therapy. }\end{array}$ & $\begin{array}{l}\text { Shimodaira } \\
\mathrm{K} \text { et al, }\end{array}$ \\
\hline $\begin{array}{l}\text { Diffuse large B-cell lymphoma } \\
(\mathrm{DLBCL})\end{array}$ & $\begin{array}{l}\text { Platelet count and albumin level are useful prognostic factors, and their combined use can } \\
\text { even predict the survival of elderly patients with DLBCL. }\end{array}$ & Ochi $Y$ et $\mathrm{al}^{34}$ \\
\hline Acute myeloid leukemia (AML) & Platelet count can predict the survival rate of patients with moderate-risk AML. & Zhang $Y$ et al, ${ }^{35}$ \\
\hline AML & $\begin{array}{l}\text { The platelet count before treatment has predictive value for the prognosis of patients with } \\
\text { non-M3 AML. }\end{array}$ & Zhang $\mathrm{Q}$ et $\mathrm{al}^{36}$ \\
\hline Breast cancer & $\begin{array}{l}\text { Platelets have important predictive value for the prognosis of patients with ipsilateral } \\
\text { supraclavicular lymph node metastasis (ISLN) in breast cancer patients, indicating that } \\
\text { platelet counts can be used to distinguish high-risk patients and thus obtain clinical benefits. }\end{array}$ & Liu $S$ et al, ${ }^{37}$ \\
\hline T-cell lymphoma & $\begin{array}{l}\text { The results of the study prove that the decrease in the number of platelets is an } \\
\text { independent prognostic factor for the survival of patients with peripheral T-cell lymphoma. }\end{array}$ & Choi $M$ et al, ${ }^{38}$ \\
\hline
\end{tabular}

thyroid nodules. ${ }^{49}$ Yin JB and colleagues retrospectively collected clinical pathological data of most patients with pancreatic cancer (PC) and assessed the relationship between MPV levels and clinical parameters. ${ }^{50}$ Survival analysis revealed that the increase in MPV was not related to the location, size, or CA19-9 of the tumour. However, elevated MPV is associated with poor survival in PC patients with concurrent liver metastases. Gallbladder cancer (GBC) represents the most common biliary malignancy. Due to the lack of typical symptoms, GBC is often detected at an advanced stage when the tumour cannot be removed or has metastasized. Therefore, there is an urgent need to identify new markers for the early detection of GBC in patients. Zhang $\mathrm{X}$ and colleagues found that the decrease in MPV and the increase in platelet distribution width (PDW) were independently related to GBC. This finding shows that MPV and PDW are available parameters for the early detection of $\mathrm{GBC}^{52}$

\section{Activated Platelets Can Participate in Tumour Formation and Progression}

Platelet activation promotes the initiation of the coagulation cascade and constitutes an important risk factor for thrombosis. Platelets activated by tumour cells further promote cancer progression through key processes such as angiogenesis and metastasis. ${ }^{76,77}$ Platelet activity can be inferred by platelet volume indices (PVIs), which include PDW, MPV, platelet distribution width-to-platelet count ratio $(\mathrm{PDW} / \mathrm{P})$, and mean platelet volume-to-platelet count ratio. ${ }^{78}$ The specific adhesion molecule P-selectin expressed on the surface of activated platelets can also promote the aggregation of neutrophils. After activation of platelets, arachidonic acid derivatives, thromboxane, platelet factor 4 (PF4) and other inflammatory mediators can be released to expand the inflammatory response. ${ }^{79}$ Thromboxane A2 (TXA2) is a product with strong physiological activity generated during the metabolism of arachidonic acid and has a strong platelet activation effect. The increased activity of TXA2 in tumour patients may indicate the presence of platelet activation in patients and play a certain role in tumour occurrence, development and metastasis. As the inhibitory effect of aspirin on TXA2 plays a role in the prevention of cancer, it is important to explore the production of TXA2 in platelets. ${ }^{80}$ After aggregation, platelets become part of the thrombus, especially the microthrombus in disseminated intravascular coagulation (DIC). Platelets and platelet-related markers, such as the platelet-to-lymphocyte ratio, are significant 
Table 2 Summary of Correlation of Mean Platelet Volume (MPV) with Tumor

\begin{tabular}{|c|c|c|}
\hline $\begin{array}{l}\text { Disease Model/Patient } \\
\text { Type }\end{array}$ & Comments & Ref. \\
\hline CRC & $\begin{array}{l}\text { MPV may be useful markers in diagnostic and early recognition of different stages of CRC; } \\
\text { additionally, combined all with neutrophil-to-lymphocyte ratio (NLR) and platelet-to- } \\
\text { lymphocyte ratio (PLR) have stronger diagnostic efficacy. }\end{array}$ & $\begin{array}{l}\text { Stojkovic } \\
\text { Lalosevic } \\
\text { M et al, }\end{array}$ \\
\hline CRC & MPV/PC may be helpful in the diagnosis of CRC. & Wu YY et al, ${ }^{26}$ \\
\hline CRC & $\begin{array}{l}\text { Serum MPV or platelet distribution width (PDW) content may be used as a predictor of } \\
\text { postoperative sepsis in patients with CRC. }\end{array}$ & Li XT et al, ${ }^{44}$ \\
\hline CRC & Elevated MPV might act as a marker of prognosis and therapeutic target for CRC. & Li N et al, ${ }^{45}$ \\
\hline $\begin{array}{l}\text { metastatic colorectal cancer } \\
(\mathrm{mCRC})\end{array}$ & $\begin{array}{l}\text { The baseline MPV level may act as a predictive factor for survival in } \mathrm{mCRC} \text { patients undergoing } \\
\text { standard chemotherapy. }\end{array}$ & Chang J et al, ${ }^{46}$ \\
\hline Colon cancer (CC) & $\begin{array}{l}\text { Increased MPV and decreased platelet distribution width (PDW) appear to be poor prognostic } \\
\text { factors in the early stages of, especially in CC patients with stage III disease. }\end{array}$ & Sakin $A$ et al, ${ }^{47}$ \\
\hline Malignant thyroid nodule & $\begin{array}{l}\text { MPV can be regarded as an auxiliary diagnostic tool to distinguish malignant and benign thyroid } \\
\text { nodules. }\end{array}$ & Sit $M$ et al, ${ }^{48}$ \\
\hline Pancreatic cancer (PC) & MPV elevated is associated with poor survival in PC patients with concurrent liver metastases. & Yin JB et al, ${ }^{49}$ \\
\hline $\begin{array}{l}\text { Pancreatic ductal } \\
\text { adenocarcinoma (PDAC) }\end{array}$ & $\begin{array}{l}\text { MPV independently predicts poor survival in PDAC patients with Type } 2 \text { diabetes mellitus } \\
\text { (T2DM). }\end{array}$ & Yin JB et al, ${ }^{50}$ \\
\hline Gallbladder cancer (GBC) & MPV and PDW are available parameters for early detection of GBC. & Zhang $X$ et $a,^{51}$ \\
\hline $\begin{array}{l}\text { Hepatocellular carcinoma } \\
(\mathrm{HCC})\end{array}$ & $\begin{array}{l}\text { Lower MPV is a risk indicator of HCC patients survival outcomes after liver transplantation } \\
\text { (LT). }\end{array}$ & Zhang $A B$ et al, ${ }^{52}$ \\
\hline $\mathrm{HCC}$ & $\begin{array}{l}\text { Thrombocytopenia and higher MPV are associated with better outcome in patients with } \\
\text { advanced HCC. }\end{array}$ & Scheiner B et al, ${ }^{21}$ \\
\hline Osteosarcoma & $\begin{array}{l}\text { The high preoperative MPV/plateletcrit ratio may serve as an independent prognostic factor } \\
\text { for a favorable prognosis in male osteosarcoma patients. }\end{array}$ & Gou B et $\mathrm{al}^{53}$ \\
\hline Esophageal cancer & Reduced MPV is associated with worse survival outcome in esophageal cancer. & Shen $W$ et al, ${ }^{54}$ \\
\hline $\begin{array}{l}\text { Esophageal squamous cell } \\
\text { carcinoma (ESCC) }\end{array}$ & $\begin{array}{l}\text { Decreased MPV and mean platelet volume/platelet count ratio (MPR) are significantly } \\
\text { associated with locally advanced ESCC. These may help the screening and risk stratification of } \\
\text { locally advanced ESCC. }\end{array}$ & Sun SY et al,,$^{55}$ \\
\hline ESCC & COP-MPV is a promising predictor for postoperative survival in ESCC patients. & Zhang $\mathrm{F}$ et al, ${ }^{56}$ \\
\hline Lung cancer & $\begin{array}{l}\text { Increased platelet count and decreased MPV are the poor prognosis of lung cancer patients, } \\
\text { and platelet count is also associated with bone, soft tissue, lymph node metastasis and } \\
\text { malignant pleural effusion. }\end{array}$ & Ohuchi $M$ et al, ${ }^{22}$ \\
\hline $\begin{array}{l}\text { Non-small cell lung cancer } \\
\text { (NSCLC) }\end{array}$ & $\begin{array}{l}\text { MPV may represent one of the easiest measuring tools as an independent prognostic marker } \\
\text { for survival in locally advanced NSCLC. }\end{array}$ & Sakin A et al, ${ }^{57}$ \\
\hline NSCLC & $\begin{array}{l}\text { The increased MPV level may be used as a prognostic biomarker to estimate for poor overall } \\
\text { survival in patients with NSCLC. }\end{array}$ & Omar $M$ et al, ${ }^{58}$ \\
\hline $\begin{array}{l}\text { Diffuse large B-cell } \\
\text { lymphoma (DLBCL) }\end{array}$ & $\begin{array}{l}\text { Low baseline MPV is an independent prognostic marker of poor outcome in patients with } \\
\qquad D L B C L .\end{array}$ & Zhou S et al, ${ }^{59}$ \\
\hline
\end{tabular}


Table 2 (Continued).

\begin{tabular}{|c|c|c|}
\hline $\begin{array}{l}\text { Disease Model/Patient } \\
\text { Type }\end{array}$ & Comments & Ref. \\
\hline DLBCL & $\begin{array}{l}\text { The pre-chemotherapy MPV value is a cheap and available parameter that may be a useful } \\
\text { prognostic marker for a significant risk of venous thromboembolism (VTE) and inferior survival } \\
\text { rates in patients with DLBCL. }\end{array}$ & $\begin{array}{l}\text { Rupa-Matysek } \\
\text { J et al, }{ }^{60}\end{array}$ \\
\hline Multiple myeloma (MM) & $\begin{array}{l}\text { The low MPV is correlated with poor prognosis in patients with MM and may serve as an } \\
\text { important indicator for disease progression and prognosis of patients with MM. }\end{array}$ & Gao $P$ et al, ${ }^{61}$ \\
\hline MM & The low MPV predicted an unfavorable prognosis in patients with MM. & Zhuang $Q$ et $\mathrm{al}^{62}$ \\
\hline Renal cell carcinoma (RCC) & Reduced MPV is identified as an independent predictor of adverse clinical outcome in RCC. & Yun ZY et al, ${ }^{63}$ \\
\hline $\begin{array}{l}\text { Clear cell renal cell } \\
\text { carcinoma }(\mathrm{ccRCC})\end{array}$ & $\begin{array}{l}\text { The mean platelet volume-to-lymphocyte ratio (MPVLR) is an easily obtainable prognostic } \\
\text { marker for overall survival in nonmetastatic ccRCC patients treated with nephrectomy. }\end{array}$ & $\begin{array}{l}\text { Życzkowski } \\
\text { M et al, }{ }^{64}\end{array}$ \\
\hline Invasive breast cancer (IBC) & High pre-treatment MPV level in IBC patients was a potential predictive factor. & Gu $M$ et ll, $^{65}$ \\
\hline $\mathrm{BC}$ & $\begin{array}{l}\text { The combination of preoperative D-Dimer and MPV improves the predictive power of } \\
\text { postoperative deep venous thrombosis risk in BC patients. }\end{array}$ & Cui LN et al, ${ }^{66}$ \\
\hline $\begin{array}{l}\text { Breast cancer with bone } \\
\text { metastases }\end{array}$ & $\begin{array}{l}\text { MPV can be used to predict the development of isolated bone metastases patients with breast } \\
\text { cancer. }\end{array}$ & $\begin{array}{l}\text { Tanriverdi } \\
\text { O et al, }{ }^{67}\end{array}$ \\
\hline $\begin{array}{l}\text { Primary malignant bone } \\
\text { tumor }\end{array}$ & $\begin{array}{l}\text { MPV and MPV/PLT ratios can be used as a diagnostic support parameter in primary malignant } \\
\text { bone tumors, but have no prognostic value. }\end{array}$ & $\begin{array}{l}\text { Sökmen FC } \\
\text { et al, }{ }^{68}\end{array}$ \\
\hline $\begin{array}{l}\text { Oral squamous cell } \\
\text { carcinoma (OSCC) }\end{array}$ & $\begin{array}{l}\text { Count of platelet (COP) -MPV score is a simple and a more effective prognostic factor than } \\
\text { other considered factors in predicting the prognosis of OSCC patients. }\end{array}$ & Park JW et al, ${ }^{69}$ \\
\hline Resectable gastric cancer & $\begin{array}{l}\text { MPV measurement can provide important diagnostic and prognostic results in patients with } \\
\text { resectable gastric cancer. }\end{array}$ & Shen $\mathrm{XM}$ et al, ${ }^{70}$ \\
\hline Prostate cancer & $\begin{array}{c}\text { The combined use of prostate specific antigen (PSA), MPV, and platelet distribution width } \\
\text { (PDW) may be clinically useful in distinguishing between prostate cancer (PCa) and benign } \\
\text { prostate hyperplasia (BPH). }\end{array}$ & Fu $S$ et al, ${ }^{71}$ \\
\hline $\begin{array}{l}\text { Laryngeal squamous cell } \\
\text { carcinoma (LSCC) }\end{array}$ & $\begin{array}{l}\text { Preoperative hyperfibrinogenemia, increased MPV and NLR were associated with reduced } \\
\text { prognosis in patients with LSCC. }\end{array}$ & Sheng $X$ et al, ${ }^{72}$ \\
\hline Ovarian cancer & $\begin{array}{l}\text { Combinations of the markers red cell distribution width (RDW), MPV, and CAI } 25 \text { may } \\
\text { improve the differential diagnosis of ovarian cancer and benign ovarian cancers. }\end{array}$ & Qin $Y Y$ et $\mathrm{al}^{73}$ \\
\hline $\begin{array}{l}\text { Differentiated thyroid } \\
\text { carcinoma (DTC) }\end{array}$ & $\begin{array}{c}\text { Their findings suggest that neutrophil-to-lymphocyte ratio (NLR), platelet-to-lymphocyte ratio } \\
\text { (PLR) and MPV changes indicate systemic inflammation that occurs after radioiodine (RAI) } \\
\text { therapy because of thyroid remnant tissue ablation. }\end{array}$ & Demir $Y$ et al, ${ }^{74}$ \\
\hline
\end{tabular}

prognostic factors in patients with breast cancer. ${ }^{81,82}$ Beili Wang and colleagues conducted a prospective study of 191 hepatocellular carcinoma (HCC) patients and 99 healthy subjects. ${ }^{83}$ Flow cytometry was used to evaluate the platelet activation state by two platelet markers, PAC-1 and CD62p. The patients who received transcatheter arterial chemoembolization (TACE) or resection treatment were monitored for $\geq 6$ months. The results demonstrated that the positive percentage of the platelet activation molecule PAC-1 is a new indicator for diagnosing and predicting the prognosis of HCC surgery. Furthermore, cancer patients generally present a hypercoagulable state. In addition, coagulation and inflammation play an important role in the pathophysiology of haematological malignancies. Elmoamly S and colleagues measured inflammatory markers in a group of 171 patients with haematological malignancies. ${ }^{84}$ The results indicated that the platelet activation marker von Willebrand Factor (vWF) was statistically related with the mortality of lymphoproliferative diseases, implying that vWF could be used as 
a prognostic marker. In addition, Shi L et al found that the platelet activation index is a potential marker for predicting gemcitabine/cisplatin (GP) resistance in the treatment of advanced and metastatic non-small cell lung cancer (NSCLC). ${ }^{85}$ In short, the data have shown that activated platelets have the potential to be tumour biomarkers.

\section{TEPs May Facilitate Blood-Based Tumour Diagnosis}

Circulating platelets interact with tumour cells during their life cycle to obtain tumour-related biomolecules; additionally, they can continuously ingest and enrich circulating free proteins, nucleic acids, vesicles and particles. ${ }^{86}$ There are two main sources of protein in the cytoplasm: one is inherited from its precursor megakaryocytes, such as platelet factor 4; the other is taken from the blood, such as P-selectin, Fibrinogen, etc.; and some proteins have both sources at the same time, such as platelet factor V. After platelets are educated, their proteome and RNA expression profile undergo significant changes, so they are called "tumour-educated platelets". ${ }^{87}$ In the process of tumour development, tumours "educate" platelets, leading to changes in their mRNA expression profiles and phenotypes. Therefore, TEP mRNA profiles have the potential to diagnose cancer and be used as biomarkers with the following advantages: 1) platelets do not contain nuclei, so genomic DNA does not interfere with them; 2) platelets are easy to collect, separate and analyse and are easy to standardize in general clinical laboratories; 3) the TEP RNA profile reflects the pathological process of cancer cells, which may provide better sensitivity for the early detection of cancer cells. ${ }^{88,89}$

The research results of Liu L et al showed that compared with healthy donors, the platelet mRNA set MAX, MTURN and HLA-B of lung cancer patients and earlystage lung cancer patients were significantly upregulated..$^{90}$ These findings suggest that the platelet mRNA set MAX, MTURN and HLA-B can facilitate blood-based lung cancer diagnosis and chemotherapy response prediction. Currently, there are no molecular biomarkers for the early detection of non-small cell lung cancer (NSCLC). However, excitingly, Shan Xing and colleagues used RNA-seq to analyse platelet RNA isolated from the blood of 9 NSCLC patients (stage I and II) and 8 healthy controls. ${ }^{91}$ The results demonstrated that TEP ITGA2B is a promising marker to improve the identification of patients with stage I NSCLC and differentiate malignant from benign lung nodules. Dong $\mathrm{X}$ et al used low-speed centrifugation to separate platelets from plasma and performed quantitative polymerase chain reaction (qPCR) to detect small nucleolar RNA SNORD55. ${ }^{92}$ The results showed that, compared with healthy controls, SNORD55 in the TEP of NSCLC patients was significantly lower, especially in early-stage patients. Importantly, they verified that TEP SNORD55 can be used as a promising biomarker for NSCLC. Chang-Liang Luo et al found that EGFRvIII RNA is present in both TEP RNA and plasma, but EGFR intracellular mutations cannot be detected in TEP DNA isolated from NSCLC. ${ }^{93}$ These data also indicate that TEP is a promising source for NSCLC diagnosis and companion diagnosis.

Yang L et al used RNA sequencing to identify gene expression signatures in platelets from colorectal cancer patients and healthy volunteers. ${ }^{94}$ Then, they verified the selected biomarkers using PCR. The results demonstrated that TIMP1 mRNA in platelets is a potential independent diagnostic biomarker for colorectal cancer, and platelets could carry RNA to colorectal cancer cells, promoting the development of colorectal cancer. Even rare malignant tumours, such as sarcomas, are a heterogeneous group caused by interstitial tissue. The recurrence rate is extremely high, and there is no method for early detection through blood-based biomarkers. Therefore, the development of blood-based liquid biopsy as a biomarker for disease recurrence monitoring would be an important step. Recently, it has been shown that TEPs have specific spliced RNA characteristics. Kimberley M. Heinhuis and colleagues tested and sequenced platelet RNA from isolated sarcoma patients (active disease), pre-sarcoma patients ( $\geq 3$ years of cancer-free) and 65 healthy donors. $^{95}$ These results indicate that liquid biopsy based on TEP RNA may be helpful for the diagnosis of sarcoma.

TEPs can participate in the systemic and local reactions of tumour growth, thereby changing the tumour RNA profile. Myron $\mathrm{G}$ et al confirmed the diagnostic potential of TEPs by sequencing the mRNA of 283 platelet samples. ${ }^{96}$ Among the six different tumour types, namely, non-small cell lung cancer, colorectal cancer, glioblastoma, pancreatic cancer, breast cancer and hepatobiliary cancer, the location of the primary tumour was correctly identified with $71 \%$ accuracy. In addition, the use of alternative TEP mRNA profiles can accurately distinguish between MET- or HER2-positive and mutant KRAS, EGFR or PIK3CA tumours. Their findings indicate that platelets provide a valuable platform for pan-cancer, 
multiple types of cancer and companion diagnosis. Sidra Asghar and colleagues found that the expression of AKT and PI3K mRNA in platelets can be used as diagnostic markers for early HCC. ${ }^{97}$ Nik Sol et al developed the digital SWARM algorithm to improve the monitoring of glioblastoma progression and demonstrated that the TEP tumour score of a single glioblastoma patient represents tumour behaviour and can be used to distinguish false positive progress from real progress. ${ }^{98}$ Finally, the combination of the TEP score and MRI analysis can enhance the detection and clinical management of patients with falsepositive glioblastoma progression.

Cancer diagnosis based on tissue biopsy has limitations because the tumour tissue is in the process of continuous development and the heterogeneity is extremely high. The current research aims to examine whether TEP may be a potential all-in-one source for blood-based cancer diagnosis to overcome the limitations of conventional cancer biopsy. Lele Liu et al also identified a platelet mRNA set: MAX, MTURN and HLA-B can achieve blood-based lung cancer diagnosis and chemotherapy response prediction. ${ }^{99}$ Chitrita Goswami et al also proposed 11 types of platelet genes (CD79B, CSDE1, IL-32, ITGA2B, LUC7L, NDUFAB1, RBM6, SKAP2, SS18L2, TRAF3IP3 and ZNF195), providing reliable and economically viable platelet-based classification between NSCLC and healthy samples. ${ }^{100}$ MicroRNAs (miRNAs) are small noncoding RNA molecules that contain approximately 18-24 nucleotides. miRNAs can regulate cell development, differentiation, the cell cycle and apoptosis. Hui Wang et al found that the expression levels of TEP miR-34c-3p and miR$18 \mathrm{a}-5 \mathrm{p}$ in nasopharyngeal carcinoma were upregulated, which has important clinical significance for the diagnosis of nasopharyngeal carcinoma. ${ }^{101}$ The results of this study also suggest that TEP miRNAs can be used as a new type of NPC diagnostic liquid biopsy.

\section{Discussion}

When a tumour occurs, some trace substances contained in platelets change. If the activated platelet response is not controlled when tissue or vascular endothelial cells are damaged, the matrix releases several mediators, such as prostanoids, growth factors, angiogenic factors, cytokines, chemokines and platelet microparticles. The proliferation of mesenchymal cells, including leukocytes and fibroblasts, not only increases the concentration of cytokines and inflammatory substances in the matrix microenvironment but also contributes to the development of chronic inflammatory reactions, which are conducive to the formation of tumours. ${ }^{102,103}$ For example, platelets can store, synthesize and release numerous angiogenic regulators to promote angiogenesis in tumours. In addition, platelets can adhere to endothelial cells through tumour cells, help tumour cells penetrate the vascular endothelium, enter the blood circulation, and form distant metastases. Due to the large number of particles in platelets, the release of the contents of the particles can promote the growth of tumour cells and resistance to radiotherapy and chemotherapy. ${ }^{104}$

Extracellular vesicles derived from platelets can also be used for liquid biopsy by using differential centrifugation, kit methods, ultrafiltration, gel filtration chromatography and other methods for the diagnosis and identification of tumour liquid biopsy, which can be applied to precision treatment. Therefore, the function of extracellular vesicles and extraction methods are also future research directions. In the studies above, not only was the number of platelets in cancer patients significantly higher than that in healthy subjects, but this number was also related to cancer progression. Abnormally elevated protein, RNA and other trace substances in the platelet granular organelles of cancer patients promote tumour occurrence, proliferation and metastasis. ${ }^{105}$ In addition, there is evidence that platelets can help tumour cells escape the immune system by directly masking the surface antigens of tumour cells, leading to tumour occurrence and development. ${ }^{106,107}$ However, liquid biopsy projects that use TEP as a molecular marker still have some limitations. One is the difficulty in the pre-analysis stage. For blood-based biomarker research, the delay between blood sampling and analysis must be as short as possible; all patients should be tested under the same conditions as much as possible to develop better comparative study; sampling must use buffer to regulate TEPs, so that the target biomarker in the study can be well preserved. Second, in patients with very small tumours or not visible on chest imaging, the low number of biomarkers in the TEPs requires high-sensitivity detection technology. The third is to detect cancer-specific biomarkers. Although encouraging results have been achieved so far, the pre-analysis processing and specific analysis steps have not been standardized, which is also an obstacle to the deployment of liquid biopsy for early cancer diagnosis in clinical practice. Further research on tumour-related platelets and their mechanisms will provide broad prospects for the early diagnosis and clinical prevention and treatment of tumours. 


\section{Acknowledgments}

This research work was supported by Natural Science Foundation (20180550488 and 2020-ZLLH-38 to Yiming Meng) of Liaoning Province, Young and middle-aged technological innovation talents in Shenyang of Yiming Meng (RC200491) and Excellent Talent Fund of Liaoning Province Cancer Hospital of Yiming Meng.

\section{Disclosure}

There are no conflicts of interest to declare.

\section{References}

1. Fernandez-Rozadilla C, Simões AR, Lleonart ME, et al. Tumor Profiling at the Service of Cancer Therapy. Front Oncol. 2021;10:595613. doi:10.3389/fonc.2020.595613

2. Brand NR, Qu LG, Chao A, Ilbawi AM. Delays and Barriers to Cancer Care in Low- and Middle-Income Countries: a Systematic Review. Oncologist. 2019;24:e1371-e1380. doi:10.1634/theoncologist.20190057

3. Kilgour E, Rothwell DG, Brady G, Dive C. Liquid Biopsy-Based Biomarkers of Treatment Response and Resistance. Cancer Cell. 2020;37:485-495. doi:10.1016/j.ccell.2020.03.012

4. von Felden J, Garcia-Lezana T, Schulze K, et al. Liquid biopsy in the clinical management of hepatocellular carcinoma. Gut 2020;69:2025-2034. doi:10.1136/gutjnl-2019-320282

5. Li C, Li J, Ni H. Crosstalk Between Platelets and Microbial Pathogens. Front Immunol. 2020;11:1962. doi:10.3389/fimmu.2020.01962

6. Ma Z, Liu S, Ke Y, et al. Biomimetic nano-NOS mediated local NO release for inhibiting cancer-associated platelet activation and disrupting tumor vascular barriers. Biomaterials. 2020;255:12 0141. doi:10.1016/j.biomaterials.2020.120141

7. Mai X, Zhang Y, Fan H, et al. Integration of immunogenic activation and immunosuppressive reversion using mitochondrial-respirationinhibited platelet-mimicking nanoparticles. Biomaterials. 2020;232:119699. doi:10.1016/j.biomaterials.2019.119699

8. Gutiérrez-Herrero S, Fernández-Infante C, Hernández-Cano L, et al. C3G contributes to platelet activation and aggregation by regulating major signaling pathways. Signal Transduct Target Ther. 2020;5:29. doi:10.1038/s41392-020-0119-9

9. Malehmir M, Pfister D, Gallage S, et al. Platelet GPIb $\alpha$ is a mediator and potential interventional target for NASH and subsequent liver cancer. Nat Med. 2019;25:641-655. doi:10.1038/s41591-019-0379-5

10. Simurda T, Zolkova J, Snahnicanova Z, et al. Identification of Two Novel Fibrinogen B $\beta$ Chain Mutations in Two Slovak Families with Quantitative Fibrinogen Disorders. Int $J$ Mol Sci. 2018;19:100. doi:10.3390/ijms 19010100

11. Marin Oyarzún CP, Heller PG. Platelets as Mediators of Thromboin flammation in Chronic Myeloproliferative Neoplasms. Front Immunol. 2019;10:1373. doi:10.3389/fimmu.2019.01373

12. Iannacone M. Platelet-mediated modulation of adaptive immunity Semin Immunol. 2016;28:555-560. doi:10.1016/j.smim.2016.10.008

13. O'Leary JG, Greenberg CS, Patton HM, Caldwell SH. AGA Clinical Practice Update: coagulation in Cirrhosis. Gastroenterology. 2019;157:34 43. doi:10.1053/j.gastro.2019.03.070

14. Wang J, Zhou X, He Y, et al. Prognostic role of platelet to lymphocyte ratio in prostate cancer: a meta-analysis. Medicine. 2018;97:e12504. doi:10.1097/MD.0000000000012504

15. Gutiontov SI, Choe KS, Miller JL, Liauw SL. Improved outcomes after radiotherapy for prostate cancer: anticoagulation, antiplatelet therapy, and platelet count as key factors in disease progression. Cancer Med. 2020;9:4667-4675. doi:10.1002/cam4.3087
16. Wang B, Li F, Cheng L, et al. The pretreatment platelet count is an independent predictor of tumor progression in patients undergoing transcatheter arterial chemoembolization with hepatitis B virus-related hepatocellular carcinoma. Future Oncol. 2019;15:827-839. doi:10.2217/fon-2018-0591

17. Oh SE, Seo JE, An JY, et al. Prognostic Impact of Increased Perioperative Platelet Count in Gastric Cancer Patients. J Surg Res. 2019;242:296-303. doi:10.1016/j.jss.2019.04.052

18. Zheng RR, Huang XX, Jin C, et al. Preoperative platelet count improves the prognostic prediction of the FIGO staging system for operable cervical cancer patients. Clin Chim Acta. 2017;473:198-203. doi:10.1016/j.cca.2016.11.008

19. Väyrynen JP, Väyrynen SA, Sirniö P, et al. Platelet count, aspirin use, and characteristics of host inflammatory responses in colorectal cancer. J Transl Med. 2019;17:199. doi:10.1186/s12967019-1950-Z

20. Midorikawa Y, Takayama T, Higaki T, et al. High platelet count as a poor prognostic factor for liver cancer patients without cirrhosis. Biosci Trends. 2020;14:368-375. doi:10.5582/bst.20 20.03230

21. Tomimaru Y, Eguchi H, Gotoh K, et al. Platelet count is more useful for predicting posthepatectomy liver failure at surgery for hepatocellular carcinoma than indocyanine green clearance test. $J$ Surg Oncol. 2016;113:565-569. doi:10.1002/jso.24166

22. Scheiner B, Kirstein M, Popp S, et al. Association of Platelet Count and Mean Platelet Volume with Overall Survival in Patients with Cirrhosis and Unresectable Hepatocellular Carcinoma. Liver Cancer. 2019;8:203-217. doi:10.1159/000489833

23. Ohuchi M, Inoue S, Ozaki Y, Ueda K. Platelet count and mean platelet volume are associated with not only bone, soft tissue, and lymph node metastases but also with malignant pleural effusion in lung cancer patients. Neoplasma. 2017;64:140-147. doi:10.4149/ neo $2017 \quad 118$

24. Qu CH, Li T, Tang ZP, et al. Platelet Count is Associated with the Rate of Lymph Node Metastasis in Lung Adenocarcinoma. Cancer Manag Res. 2020;12:9765-9774. doi:10.2147/CMAR. S273328

25. Xu L, Xu F, Kong H, et al. Effects of reduced platelet count on the prognosis for patients with non-small cell lung cancer treated with EGFR-TKI: a retrospective study. BMC Cancer. 2020;20:1152. doi:10.1186/s12885-020-07650-2

26. Pardo L, Valero C, López M, et al. The prognostic value of pretreatment platelet count in patients with head and neck squamous cell carcinoma. Auris Nasus Larynx. 2017;44:313-318. doi:10.1016/j.anl.2016.06.009

27. Wu YY, Zhang X, Qin YY, et al. Mean platelet volume/platelet count ratio in colorectal cancer: a retrospective clinical study. BMC Cancer. 2019;19:314. doi:10.1186/s12885-019-5504-9

28. Stojkovic Lalosevic M, Pavlovic Markovic A, Stankovic S, et al. Combined Diagnostic Efficacy of Neutrophil-to-Lymphocyte Ratio (NLR), Platelet-to-Lymphocyte Ratio (PLR), and Mean Platelet Volume (MPV) as Biomarkers of Systemic Inflammation in the Diagnosis of Colorectal Cancer. Dis Markers. 2019;2019:6036979. doi:10.1155/2019/6036979

29. Chen LL, Zhang L, Li YL, et al. Association of preoperative platelet count with the prognosis of patients with colorectal cancer. Nan Fang Yi Ke Da Xue Xue Bao. 2016;36:482-487.

30. Belluco C, Forlin M, Delrio P, et al. Elevated platelet count is a negative predictive and prognostic marker in locally advanced rectal cancer undergoing neoadjuvant chemoradiation: a retrospective multi-institutional study on 965 patients. $B M C$ Cancer. 2018;18:1094. doi:10.1186/s12885-018-5022-1

31. Watrowski R, Heinze G, Jäger C, et al. Usefulness of the preoperative platelet count in the diagnosis of adnexal tumors. Tumour Biol. 2016;37:12079-12087. doi:10.1007/s13277-016$5090-2$ 
32. Yilmaz E, Coskun EI, Sahin N, et al. MPV, NLR, and platelet count: new hematologic markers in diagnosis of malignant ovarian tumor. Eur J Gynaecol Oncol. 2017;38:346-349.

33. Hu Q, Hada A, Han L. Platelet count as a biomarker for monitoring treatment response and disease recurrence in recurrent epithelial ovarian cancer. J Ovarian Res. 2020;13:78. doi:10.1186/ s13048-020-00682-z

34. Shimodaira K, Nakashima J, Nakagami Y, et al. Prognostic Value of Platelet Counts in Patients with Metastatic Prostate Cancer Treated with Endocrine Therapy. Urol J. 2020;17:42-49. doi:10.22037/uj.v0i0.4735

35. Ochi Y, Kazuma Y, Hiramoto N, et al. Utility of a simple prognostic stratification based on platelet counts and serum albumin levels in elderly patients with diffuse large B cell lymphoma. Ann Hematol. 2017;96:1-8. doi:10.1007/s00277-016-2819-3

36. Zhang Y, Gu H, Chen Q, et al. Low Platelet Counts at Diagnosis Predict Better Survival for Patients with Intermediate-Risk Acute Myeloid Leukemia. Acta Haematol. 2020;143:9-18. doi:10.1159/ 000500230

37. Zhang Q, Dai K, Bi L, et al. Pretreatment platelet count predicts survival outcome of patients with de novo non-M3 acute myeloid leukemia. PeerJ. 2017;5:e4139. doi:10.7717/peerj.4139

38. Liu S, Fang J, Jiao D, Liu Z. Elevated Platelet Count Predicts Poor Prognosis in Breast Cancer Patients with Supraclavicular Lymph Node Metastasis. Cancer Manag Res. 2020;12:6069-6075. doi:10.2147/CMAR.S257727

39. Choi M, Lee JO, Jung J, et al. Prognostic Value of Platelet Count in Patients with Peripheral T Cell Lymphoma. Acta Haematol. 2019;141:176-186. doi:10.1159/000495337

40. Korniluk A, Koper-Lenkiewicz OM, Kamińska J, et al. Mean Platelet Volume (MPV): new Perspectives for an Old Marker in the Course and Prognosis of Inflammatory Conditions. Mediators Inflamm. 2019;2019:9213074. doi:10.1155/2019/9213074

41. Crafa A, Condorelli RA, Mongioì LM, et al. Mean Platelet Volume as a Marker of Vasculogenic Erectile Dysfunction and Future Cardiovascular Risk. J Clin Med. 2020;9:2513. doi:10.3390/jcm9082513

42. Akingbade OES, Gibson C, Kalaria RN, Mukaetova-Ladinska EB. Platelets: peripheral Biomarkers of Dementia? J Alzheimers Dis. 2018;63:1235-1259. doi:10.3233/JAD-180181

43. Barale C, Russo I. Influence of Cardiometabolic Risk Factors on Platelet Function. Int $J$ Mol Sci. 2020;21:623. doi:10.3390/ ijms21020623

44. Desborough MJ, Oakland K, Brierley C, et al. Desmopressin use for minimising perioperative blood transfusion. Cochrane Database Syst Rev. 2017;7:CD001884. doi:10.1002/14651858.CD001884.pub3

45. Li XT, Yan Z, Wang RT, Yu KJ. Preoperative Mean Platelet Volume and Platelet Distribution Width Predict Postoperative Sepsis in Patients with Colorectal Cancer. Biomed Res Int. 2019;2019:9438750. doi:10.1155/2019/9438750

46. Li N, Yu Z, Zhang X, et al. Elevated mean platelet volume predicts poor prognosis in colorectal cancer. Sci Rep. 2017;7:10261. doi:10.1038/s41598-017-11053-y

47. Chang J, Lin G, Ye M, et al. Decreased mean platelet volume predicts poor prognosis in metastatic colorectal cancer patients treated with first-line chemotherapy: results from $\mathrm{mCRC}$ biomarker study. $B M C$ Cancer. 2019;19:15. doi:10.1186/s12885-018-5252-2

48. Sakin A, Sahin S, Sakin A, et al. Mean platelet volume and platelet distribution width correlates with prognosis of early colon cancer. J BUON. 2020;25:227-239.

49. Sit M, Aktas G, Ozer B, et al. Mean platelet volume: an overlooked herald of malignant thyroid nodules. Acta Clin Croat. 2019;58:417-420. doi:10.20471/acc.2019.58.03.03

50. Yin JB, Wang X, Zhang X, et al. Mean platelet volume predicts survival in pancreatic cancer patients with synchronous liver metastases. Sci Rep. 2018;8:6014. doi:10.1038/s41598-018-24539-0
51. Yin JB, Li N, Cui MM, et al. Reduced mean platelet volume levels predict shorter survival in patients with resectable pancreatic ductal adenocarcinoma and type 2 diabetes. $B M C$ Gastroenterol. 2020;20:143. doi:10.1186/s12876-020-01225-y

52. Zhang X, Niu Y, Wang X, et al. Mean Platelet Volume and Platelet Distribution Width Are Associated with Gallbladder Cancer. Asian Pac J Cancer Prev. 2014;19:351-355.

53. Zhang $\mathrm{AB}$, Zhang $\mathrm{ZH}$, Zhang $\mathrm{J}$, et al. Lower mean platelet volume is a risk indicator of hepatocellular carcinoma recurrence following liver transplantation. Hepatobiliary Pancreat Dis Int. 2019;18:223-227. doi:10.1016/j.hbpd.2019.04.009

54. Gou B, Cao H, Cheng X, et al. Prognostic value of mean platelet volume to plateletcrit ratio in patients with osteosarcoma. Cancer Manag Res. 2019;11:1615-1621. doi:10.2147/CMAR.S193949

55. Shen W, Cui MM, Wang X, Wang RT. Reduced mean platelet volume is associated with poor prognosis in esophageal cancer. Cancer Biomark. 2018;22:559-563. doi:10.3233/CBM-181231

56. Sun SY, Zhao BQ, Wang J, et al. The clinical implications of mean platelet volume and mean platelet volume/platelet count ratio in locally advanced esophageal squamous cell carcinoma. Dis Esophagus. 2018;31:31. doi:10.1093/dote/dox125

57. Zhang F, Chen Z, Wang P, et al. Combination of platelet count and mean platelet volume (COP-MPV) predicts postoperative prognosis in both resectable early and advanced stage esophageal squamous cell cancer patients. Tumour Biol. 2016;37:9323-9331. doi:10.1007/s13277-015-4774-3

58. Sakin A, Secmeler S, Arici S, et al. Prognostic Significance of Mean Platelet Volume on Local Advanced Non-Small Cell Lung Cancer Managed with Chemoradiotherapy. Sci Rep. 2019;9:3959. doi:10.1038/s41598-019-40589-4

59. Omar M, Tanriverdi O, Cokmert S, et al.; Turkish Descriptive Oncological Researches Group. Role of increased mean platelet volume (MPV) and decreased MPV/platelet count ratio as poor prognostic factors in lung cancer. Clin Respir J. 12;2018:92 2-929. doi:10.1111/crj.12605

60. Zhou S, Ma Y, Shi Y, et al. Mean platelet volume predicts prognosis in patients with diffuse large B-cell lymphoma. Hematol Oncol. 2018;36:104-109. doi:10.1002/hon.2467

61. Rupa-Matysek J, Gil L, Kroll-Balcerzak R, et al. Mean platelet volume as a predictive marker for venous thromboembolism and mortality in patients treated for diffuse large B-cell lymphoma. Hematol Oncol. 2017;35:456-464. doi:10.1002/hon.2321

62. Gao P, Xiao ZP, Fu K, Han M. Clinical significance of mean platelet volume determination in multiple myeloma. Zhongguo Shi Yan Xue Ye Xue Za Zhi. 2017;25:827-831. doi:10.7534/j. issn.1009-2137.2017.03.035

63. Zhuang Q, Xiang L, Xu H, et al. The independent association of mean platelet volume with overall survival in multiple myeloma. Oncotarget. 2016;7:62640-62646. doi:10.18632/oncotarget.11 551

64. Yun ZY, Zhang X, Liu YS, et al. Lower mean platelet volume predicts poor prognosis in renal cell carcinoma. Sci Rep. 2017;7:6700. doi:10.1038/s41598-017-07168-x

65. Życzkowski M, Kaletka Z, Rajwa P, et al. Mean platelet volume-to-lymphocyte ratio: a novel biomarker associated with overall survival in patients with nonmetastatic clear cell renal cell carcinoma treated with nephrectomy. Int Urol Nephrol. 2020;52:885-891. doi:10.1007/s11255-020-02379-0

66. Gu M, Zhai Z, Huang L, et al. Pre-treatment mean platelet volume associates with worse clinicopathologic features and prognosis of patients with invasive breast cancer. Breast Cancer. 2016;23:752-760. doi:10.1007/s12282-015-0635-6

67. Cui LN, Li N, Fu S, et al. Combination of preoperative D-dimer and mean platelet volume predicts postoperative deep venous thrombosis in breast cancer patients. Cancer Biomark. 2018;21:909-913. doi:10.3233/CBM-170975 
68. Tanriverdi O, Menekse S, Teker F, et al. The mean platelet volume may predict the development of isolated bone metastases in patients with breast cancer: a retrospective study of the Young Researchers Committee of the Turkish Oncology Group (TOG). J BUON. 2016;21:840-850.

69. Sökmen FC, Ulucaköy C. Diagnostic and prognostic role of mean platelet volume and mean platelet volume/platelet ratio in patients with primary malignant bone tumor. Jt Dis Relat Surg. 2021;32:198-203. doi:10.5606/ehc.2021.76357

70. Park JW, Kim CH, Ha YC, et al. Count of platelet and mean platelet volume score: serologic prognostic factor in patients with oral squamous cell carcinoma. J Korean Assoc Oral Maxillofac Surg. 2017;43:305-311. doi:10.5125/jkaoms.2017.43.5.305

71. Shen XM, Xia YY, Lian L, et al. Mean platelet volume provides beneficial diagnostic and prognostic information for patients with resectable gastric cancer. Oncol Lett. 2016;12:2501-2506. doi:10.3892/ol.2016.4913

72. Fu S, Zhang X, Niu Y, Wang RT. Prostate specific antigen, mean platelet volume, and platelet distribution width in combination to discriminate prostate cancer from benign prostate hyperplasia. Asian Pac J Cancer Prev. 2018;19:699-702. doi:10.22034/ APJCP.2018.19.3.699

73. Sheng X, Zhang H, Ge P, et al. A Retrospective Study of The Prognostic Significance of Preoperative Plasma Fibrinogen, Mean Platelet Volume, and the Neutrophil-to-Lymphocyte Ratio in Patients with Laryngeal Squamous Cell Carcinoma. Med Sci Monit. 2019;25:4527-4534. doi:10.12659/MSM.914426

74. Qin YY, Wu YY, Xian XY, et al. Single and combined use of red cell distribution width, mean platelet volume, and cancer antigen 125 for differential diagnosis of ovarian cancer and benign ovarian tumors. J Ovarian Res. 2018;11:10.

75. Demir Y, Üçler R, Sürücü E, et al. Temporary changes in neutrophil-to-lymphocyte, platelet-to-lymphocyte ratios, and mean platelet volume reflecting the inflammatory process after radioiodine therapy. Nucl Med Commun. 2016;37:393-398. doi:10.1097/MNM.0000000000000452

76. Suzuki-Inoue K. Platelets and cancer-associated thrombosis: focusing on the platelet activation receptor CLEC-2 and podoplanin. Blood. 2019;134:1912-1918. doi:10.1182/blood.2019001388

77. Koupenova M, Clancy L, Corkrey HA, Freedman JE. Circulating Platelets as Mediators of Immunity, Inflammation, and Thrombosis. Circ Res. 2018;122:337-351.

78. Kelly K, Cancelas JA, Szczepiorkowski ZM, et al. Frozen Platelets-Development and Future Directions. Transfus Med Rev. 2020;34:286-293. doi:10.1016/j.tmrv.2020.09.008

79. Hisada Y, Mackman N. Cancer-associated pathways and biomarkers of venous thrombosis. Blood. 2017;130:1499-1506. doi:10.1182/blood-2017-03-743211

80. Amanda J, Unsworth AP, Sage T, et al. Anti-platelet properties of Pim kinase inhibition is mediated through disruption of thromboxane A2 receptor signalling. Haematologica. 2019.

81. Corbeau I, Thezenas S, Maran-Gonzalez A, et al. Inflammatory blood markers as prognostic and predictive factors in early breast cancer patients receiving neoadjuvant chemotherapy. Cancers. 2020;12:2666. doi:10.3390/cancers12092666

82. Takeuchi H, Kawanaka H, Fukuyama S, et al. Comparison of the prognostic values of preoperative inflammation-based parameters in patients with breast cancer. PLoS One. 2017;12:e177137. doi:10.1371/journal.pone.0177137

83. Wang B, Zhu J, Ma X, et al. Platelet activation status in the diagnosis and postoperative prognosis of hepatocellular carcinoma. Clin Chim Acta. 2019;495:191-197. doi:10.1016/j.cca.2019.03.1634

84. Elmoamly S, Afif A. Can biomarkers of coagulation, platelet activation, and inflammation predict mortality in patients with hematological malignancies? Hematology. 2018;23:89-95. doi:10.1080/10245332.2017.1365458
85. Shi L, Li Y, Yu T, et al. Predictable resistance and overall survival of gemcitabine/cisplatin by platelet activation index in non-small cell lung cancer. Med Sci Monit. 2018;24:8655-8668. doi:10.12659/MSM.911125

86. Dovizio M, Ballerini P, Fullone R, et al. Multifaceted Functions of Platelets in Cancer: from Tumorigenesis to Liquid Biopsy Tool and Drug Delivery System. Int J Mol Sci. 2020;21:9585. doi:10.3390/ijms21249585

87. Cirillo M, Craig AFM, Borchmann S, Kurtz DM. Liquid biopsy in lymphoma: molecular methods and clinical applications. Cancer Treat Rev. 2020;91:102106. doi:10.1016/j.ctrv.2020.10 2106

88. Sol N, Wurdinger T. Platelet RNA signatures for the detection of cancer. Cancer Metastasis Rev. 2017;36:263-272. doi:10.1007/ s10555-017-9674-0

89. Best MG, Vancura A, Wurdinger T. Platelet RNA as a circulating biomarker trove for cancer diagnostics. J Thromb Haemost. 2017;15:1295-1306. doi:10.1111/jth.13720

90. Liu L, Song X, Li X, et al. A three-platelet mRNA set: MAX, MTURN and HLA-B as biomarker for lung cancer. $J$ Cancer Res Clin Oncol. 2019;145:2713-2723. doi:10.1007/s00432-019-030 32-9

91. Xing S, Zeng T, Xue N, et al. Development and Validation of Tumor-educated Blood Platelets Integrin Alpha 2b (ITGA2B) RNA for Diagnosis and Prognosis of Non-small-cell Lung Cancer through RNA-seq. Int J Biol Sci. 2019;15:1977-1992. doi:10.7150/ijbs.36284

92. Dong X, Song X, Ding S, et al. Tumor-educated platelet SNORD55 as a potential biomarker for the early diagnosis of non-small cell lung cancer. Thorac Cancer. 2020. doi:10.1111/ 1759-7714.13823

93. Luo $\mathrm{CL}, \mathrm{Xu} \mathrm{ZG}$, Chen $\mathrm{H}$, et al. LncRNAs and EGFRvIII sequestered in TEPs enable blood-based NSCLC diagnosis. Cancer Manag Res. 2018;10:1449-1459. doi:10.2147/CMAR. $\mathrm{S} 164227$

94. Yang L, Jiang Q, Li DZ, et al. TIMP1 mRNA in tumor-educated platelets is diagnostic biomarker for colorectal cancer. Aging. 2019;11:8998-9012. doi:10.18632/aging.102366

95. Heinhuis KM, In 'T Veld SGJG, Dwarshuis G. RNA-Sequencing of tumor-educated platelets, a novel biomarker for blood-based sarcoma diagnostics. Cancers. 2020;12(6):1372. doi:10.3390/ cancers 12061372

96. Best MG, Sol N, Kooi I, et al. RNA-seq of tumor-educated platelets enables blood-based pan-cancer, multiclass, and molecular pathway cancer diagnostics. Cancer Cell. 2015;28:666-676. doi:10.1016/j.ccell.2015.09.018

97. Asghar S, Waqar W, Umar M, Manzoor S. Tumor educated platelets, a promising source for early detection of hepatocellular carcinoma: liquid biopsy an alternative approach to tissue biopsy. Clin Res Hepatol Gastroenterol. 2020;44:836-844. doi:10.1016/j. clinre.2020.03.023

98. Sol N. Tumor-Educated Platelet RNA for the Detection and (Pseudo)progression Monitoring of Glioblastoma. Cell Rep Med. 2020;1:100101. doi:10.1016/j.xcrm.2020.100 101

99. Liu L, Song X, Li X, et al. A three-platelet mRNA set: MAX, MTURN and HLA-B as biomarker for lung cancer. $J$ Cancer Res Clin Oncol. 2019;145(11):2713-2723.

100. Goswami C, Chawla S, Thakral D, et al. Molecular signature comprising 11 platelet-genes enables accurate blood-based diagnosis of NSCLC. BMC Genomics. 2020;21:744. doi:10.1186/ s12864-020-07147-z

101. Wang H, Wei X, Wu B, et al. Tumor-educated platelet miR-34c$3 p$ and miR-18a-5p as potential liquid biopsy biomarkers for nasopharyngeal carcinoma diagnosis. Cancer Manag Res. 2019;11:3351-3360. doi:10.2147/CMAR.S195654 
102. De Palma M, Biziato D, Petrova TV. Microenvironmental regulation of tumour angiogenesis. Nat Rev Cancer. 2017;17:457-474. doi:10.1038/nrc.2017.51

103. Luo Z, Wang Q, Lau WB, et al. Tumor microenvironment: the culprit for ovarian cancer metastasis? Cancer Lett. 2016;377 (2):174-182. doi:10.1016/j.canlet.2016.04.038

104. Cho MS, Jiasong L, Gonzalez-Delgado R, et al. The effect of platelet $\mathrm{G}$ proteins on platelet extravasation and tumor growth in the murine model of ovarian cancer. Blood Adv. 2021;5: 1947-1951. doi:10.1182/bloodadvances.2020003410
105. Li Z, Hu S, Cheng K. Platelets and their biomimetics for regenerative medicine and cancer therapies. $J$ Mater Chem $B$. 2018;6:7354-7365. doi:10.1039/C8TB02301H

106. Maurer S, Ferrari de Andrade L. NK cell interaction with platelets and myeloid cells in the tumor milieu. Front Immunol. 2020;11:608849. doi:10.3389/fimmu.2020.608849

107. Garrido-Navas C, de Miguel-perez D, Exposito-Hernandez J, et al. Cooperative and escaping mechanisms between circulating tumor cells and blood constituents. Cells. 2019;8:1382. doi:10.3390/cells 8111382

\section{Publish your work in this journal}

OncoTargets and Therapy is an international, peer-reviewed, open access journal focusing on the pathological basis of all cancers, potential targets for therapy and treatment protocols employed to improve the management of cancer patients. The journal also focuses on the impact of management programs and new therapeutic

Submit your manuscript here: https://www.dovepress.com/oncotargets-and-therapy-journal agents and protocols on patient perspectives such as quality of life, adherence and satisfaction. The manuscript management system is completely online and includes a very quick and fair peer-review system, which is all easy to use. Visit http://www.dovepress.com/ testimonials.php to read real quotes from published authors. 